\title{
Single dose oral toxicity study of Picrorhiza kurroa rhizome extract in Wistar rats
}

\author{
Acharya Bal Krishna1,2, Hemanth Kumar Manikyam², Vinay K Sharma ${ }^{2}$ and Niti Sharma² \\ ${ }^{1}$ University of Patanjali, Haridwar, Uttarakhand 249402, India \\ ${ }_{2}^{2}$ Patanjali Natural Coloroma Pvt Ltd, Haridwar, Uttarakhand 249404, India
}

(Received December 22, 2015; Accepted January 4, 2016)

\begin{abstract}
Picrorhiza kurroa is a well-known ayurvedic or herbal medicine which is used very commonly in the treatment of various diseases. Therefore, we studied the oral toxicity of Picrorhiza kurroa rhizome extract in rats. A single high dose of the extract at $2000 \mathrm{mg} / \mathrm{kg}$ body weight was tested on Wistar rats. Mortality/viability and clinical signs were recorded on test day 0 (prior to administration), 7, 14 and at death. All animals appeared normal from day one to throughout the experimental procedure. Picrorhiza kurroa rhizome extract is non-toxic to rats and helped in weight gain with $\mathrm{LD}_{50}>2000 \mathrm{mg} / \mathrm{kg}$ body weight. Oral administration of Picrorhiza kurroa is not connected with any toxicologically significant effects and the data could provide satisfactory preclinical evidence of safety to launch a clinical trial on a standardized formulation of the plant extracts.
\end{abstract}

Key words: Picrorhiza kurroa, Hydroalcoholic extract, Wistar rats

\section{INTRODUCTION}

Picrorhiza kurroa Royle ex. Benth (Family Scrophularaceae) commonly called Kutki or Kutka is a recognized herb in the Ayurvedic and Chinese system of traditional medicine. It is a wonder herb with hepatoprotective (Visen et al., 1998; Saraswat et al., 1999; Singh et al., 2005; Shetty et al., 2010; Singh and Sharma, 2011), anticholestatic (Shukla et al., 1991), antioxidant (Kant et al., 2013), antidiabetic (Husain et al., 2009) and immunemodulating properties (Labadie et al., 1989; Chevallier, 1996)

The leaves, root and rhizome of Picrorhiza are used to treat liver and upper respiratory tract disorders, chronic diarrhea, and scorpion sting. It is also effective in treating a variety of diseases ranging from digestion problems to malaria, jaundice, allergy, epilepsy, paralysis, rheumatoid arthritis and skin diseases (Krishnamurthy, 1969; Baruah et al., 1999; Irshad et al., 2011; Banyal et al., 2014; Pathan and Ambavade, 2014). The main active ingredients of Picrorhiza are kutkin, picrorrhizin, kutkisterol, iridoid glycosides (picroside I-III), apocynin, drosin, and nine cucurbitacin glycosides etc. (Basu et al., 1970; Atal et al., 1986) which might have role in stimulating the immune system, kill cancer cells, and relieve inflam- mation (Simons et al., 1990). The hepatoprotective action of Picrorhiza kurroa may be attributed to its free radical scavenging activity (Russo et al., 2001). Additionally, it has been shown to stimulate liver regeneration in rats, probably by increasing nucleic acid and protein synthesis (Singh et al., 1992). The constituents of Picrorhiza have shown to inhibit histamine release, decrease mast cell activity and prevented allergen- and platelet activating factor-induced bronchial obstruction (Dorsch et al., 1991; Baruah et al., 1998). Picrorhiza extract may be of therapeutic value in treating viral hepatitis as it has promising anti-hepatitis B surface antigen activity (Mehrotra et al., 1990). In rats infected with malaria, Picrorhiza restored depleted glutathione levels, thereby enhancing detoxification and antioxidation, thereby maintaining a normal oxidation-reduction balance (Chander et al., 1992).

Nowadays plants or plant extracts have important therapeutical application in both Western and Eastern medicinal systems. However, some of them are potentially toxic, mutagenic or carcinogenic thus their toxicity profile is essential for the use as medicine. Therefore, in the current article we prepared different doses of standardized hydroalcoholic extract of Picrorhiza kurroa rhizome and tested them on Wistar rats to assess the toxicity.

Correspondence: Niti Sharma (E-mail: nitivinay@yahoo.co.in) 


\section{A. Bal Krishna et al.}

\section{MATERIAL AND METHODS}

\section{Material and extraction}

Picrorhiza kurroa rhizomes were procured from Patanjali Natural Coloroma and stored in ambient conditions for further study. The other solvents and chemicals were purchase from Sigma-Aldrich, India.

The powdered Picrorhiza kurroa rhizomes were subjected to extraction using Methanol: Water (60:40). The extract was evaporated to dryness in a rotary flash evaporator at a temperature not exceeding $60^{\circ} \mathrm{C}$, and then stored in air tight container.

The study was conducted following the Standard Operating Procedures (SOPs). Fixed Dose Procedure was practiced based on OECD 420-OECD Principles of Good Laboratory Practice for the testing of chemicals as specified by International [C (97) 186/Final] Legislation.

\section{Test system}

Wistar rats (male and female rats between 4-6 weeks of age), were obtained from RCC, laboratories, Hyderabad. The animals were sexually mature and the females were nulliparous and non-pregnant. At study initiation the age of the rats was 6-8 weeks and the body weight of male and female rats ranged between 156.5-185 g and 129-144 g, respectively.

The animals were acclimatized for a period of 5 days during which individual rats were subjected to physical examinations and assessed for their health condition and suitability to be included into the study. During the acclimatization period, each animal was observed at least once a day, to determine any abnormalities, infighting inflicted injuries or disease. Only those animals certified by the in-house veterinarian as healthy, were used for the study. After randomization rats were housed in 2 rats per cage of same sex. Animals were identified by a unique fur (body) marking using $10 \%$ picric acid.

All rats had free access to sterilize water and standard pelleted laboratory animal diet (Vetcare Feeds, Promini, India). Autoclaved Corn cob was used as bedding material and was changed once in three days. Periodic analysis for bacterial and chemical contaminations on feed, water and bedding material were carried out in the Animal House, as per existing SOPs and the data thereof, are maintained in the Animal House. Throughout the acclimation and dosing period, animal room temperature and relative humidity was maintained at $18^{\circ} \mathrm{C}-23.2^{\circ} \mathrm{C}$ and $35 \%$ to $78 \% \mathrm{RH}$, respectively. Illumination was controlled to give $12 \mathrm{hr}$ light (7.00 a.m. to 7.00 p.m.) and $12 \mathrm{hr}$ dark cycle during the $24-\mathrm{hr}$ period.

\section{Preparation of dose formulation}

The concentrations of the Test sample prepared for dosing were 10,50 and $100 \mathrm{mg} / \mathrm{mL}$, to administer doses of Active Ingredient (AI) equivalent to 200, 1000 and $2000 \mathrm{mg} / \mathrm{kg}$ to animals of Group 2, Group 3 and Group 4, respectively. Group 1 animals were treated with vehicle control ( $0.5 \%$ aqueous carboxy methylcellulose). (Table 1$)$

\section{Statistical analysis}

Group mean and standard deviation were calculated for all generated data using Barlett's test for intra group variances. The data with homogeneous intra-group variances was subjected to one-way analysis of variance ANOVA (Snedecor and Cochran, 1980) and Dunnett's pair-wise comparison (Scheffe, 1953), to confirm significance in the ANOVA test. All statistical analysis and comparisons was determined at $\mathrm{P}<$ or $=0.05$ level.

\section{RESULTS}

No mortality/morbidity was observed in any of the male and female rats, at and up to dose of $2000 \mathrm{mg} / \mathrm{kg}$ body weight after the oral administration of Test sample for 14 days of study period. No remarkable abnormal clinical signs, in any of the treated male or female rats

Table 1. The study design.

\begin{tabular}{lcccc}
\hline Group & Dose $(\mathrm{mg} / \mathrm{kg})$ & Concentration $(\mathrm{mg} / \mathrm{mL})$ & Dose Volume $(\mathrm{mL} / \mathrm{kg})$ & Number of Rats \\
\hline Control (G1) & 0 & 0 & 20 & 5 \\
\hline Low Dose (G2) & 200 & 10 & 20 & 5 \\
\hline Mid Dose (G3) & 1000 & 50 & 20 & 5 \\
\hline High Dose (G4) & 2000 & 100 & F & 5 \\
\hline
\end{tabular}


Oral toxicity study of Picrorhiza kurroa

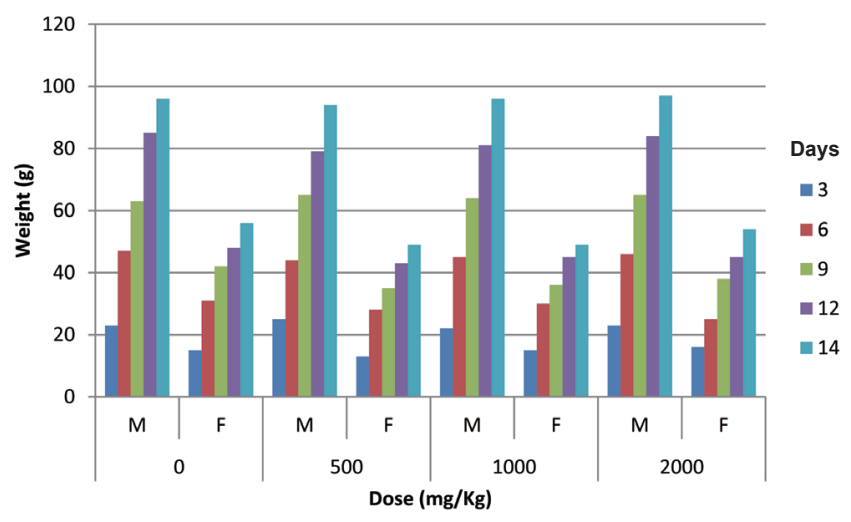

Fig. 1. Cumulative net body weight gain $(\mathrm{g})$ in male and female rats.

were observed. The group mean body weights of male and female rats treated with Test sample at and up to the dose of $2000 \mathrm{mg} / \mathrm{kg}$ did not differ significantly from those of the controls during the 14 day treatment period. The cumulative net body weight gain, computed over the period of 14 days, in rats receiving Test sample at 500, 1000 or $2000 \mathrm{mg} / \mathrm{kg}$ is displayed in Fig. 1. The values of average daily food consumption by male and female rats exposed to Test sample at and up to the dose of $2000 \mathrm{mg} / \mathrm{kg}$ were found to be comparable to those of the concurrent control groups. The Test sample, at and up to the level of $2000 \mathrm{mg} / \mathrm{kg}$, did not induce any treatment related gross pathological alterations in any of the vital organs/tissues of treated rats.

In conclusion, based on the findings of this study, the Maximum Tolerated Dose of Test sample in Wistar rats following two fractional gavage doses on a single day was found to be $>2000 \mathrm{mg} / \mathrm{kg}$ body weight, under the conditions of this study. Thus hydroalcoholic extract of Picrorhiza kurroa rhizome is non-toxic to Wistar rats and helped in weight gain. To summarize, the results of this study collectively specify that oral administration of Picrorhiza kurroa is not connected with any toxicologically significant effects and the data could provide satisfactory preclinical evidence of safety to launch a clinical trial on a standardized formulation of the plant extracts.

\section{ACKNOWLEDGMENT}

We are thankful to Patanjali Ayurved Ltd., Haridwar, India for providing plant material for the study.
Conflict of interest---- The authors declare that there is no conflict of interest.

\section{REFERENCES}

Atal, C.K., Sharma, M.L., Kaul, A. and Khajuria, A. (1986): Immunomodulatory agents of plant origin: preliminary screening. J. Ethnopharmacol., 18, 131-141.

Banyal, H.S., Devi, R. and Devi, N. (2014): Picrorhiza kurroa Royal ex Benth exhibits antimalarial activity against Plasmodium berghei vincke and lips, 1948. Asian J. Biol. Sci., 7, 72-75.

Baruah, C.C., Guptau, P.P., Nath, A., Patnaik, G.K. and Dhawan, B.N. (1998): Anti-allergic and anti-anaphylactic activity of picroliv - a standardized iridoid glycoside fraction of Picrorhiza kurrooa. Pharmacol. Res., 38, 487-492.

Basu, K., Dasgupta, B. and Ghosal, S. (1970): Chemistry of kutkin isolated from Picrorhiza kurroa Royle ex Benth. Experientia, 26, 818-819.

Chander, R., Kapoor, N.K. and Dhawan, B.N. (1992): Picroliv, picroside-I and kutkoside from Picrorhiza kurroa are scavengers of superoxide anions. Biochem. Pharmacol., 4, 180-183.

Chevallier, A. (1996): The Encyclopaedia of Medicinal Plants Dorling Kindersley, London, UK. pp. 336.

Dorsch, W., Stuppner, H., Wagner, H., Gropp, M., Demoulin, S. and Ring, J. (1991): Antiasthmatic effects of Picrorhiza kurroa: androsin prevents allergen- and PAF-induced bronchial obstruction in guinea pigs. Int. Arch. Allergy Appl. Immunol., 95, 128133.

Husain, G.M., Singh, P.N. and Kumar, V. (2009): Antidiabetic activity of standardized extract of Picrorhiza kurroa in rat model of NIDDM. Drug Discov. Ther., 3, 88-92.

Irshad, S., Mannan, A. and Mirza, B. (2011): Antimalarial activity of three Pakistani medicinal plants Pak. J. Pharm. Sci., 24, 589591.

Kant, K., Walia, M., Agnihotri, V.K., Pathania, V. and Singh, B. (2013): Evaluation of Antioxidant activity of Picrorhiza kurroa (Leaves) extracts. Indian J. Pharm. Sci., 75, 324-329.

Krishnamurthy, A. (1969): The Wealth of India vol VIII. New Delhi, Publication and Information Directorate, Council of Scientific and Industrial Research, p.49.

Labadie, R.P., van der Nat, J.M., Simons, J.M., Kroes, B.H., Kosasi, S., van den Berg, A.J., t' Hart, L.A., van der Sluis, W.G., Abeysekera, A., Bamunuarachchi, A. and De Silva, K.T.D. (1989): An ethnopharmacognostic approach to the search for immunomodulators of plant origin. Planta Med., 55, 339-348.

Mehrotra, R., Rawat, S. and Kulshreshtha, D.K. (1990): In vitro studies on the effect of certain natural products against hepatitis B virus. Indian J. Med. Res., 92, 133-138.

Pathan, D. and Ambavade, S. (2014): Anticonvulsant activity of ethanolic extract of Picrorhiza kurroa. Pharmacophore, 5, 141-146.

Russo, A., Izzo, A.A., Cardile, V., Borrelli, F. and Vanella, A. (2001): Indian medicinal plants as antiradicals and DNA cleavage protectors. Phytomed., 8, 125-132.

Saraswat, B., Visen, P.K., Patnaik, G.K. and Dhawan, B.N. (1999): Ex vivo and in vivo investigations of picroliv from Picrorhiza kurroa in an alcohol intoxication model in rats. J. Ethnopharmacol., 66, 263-269.

Scheffe, H. (1953): A Method for judging all Contrasts in the Analysis of Variance. Biometrika, 40, 87-104.

Shetty, S.N., Mengi, S., Vaidya, R. and Vaidya, A.D. (2010): A study of standardized extracts of Picrorhiza kurroa Royle ex Benth 


\section{A. Bal Krishna et al.}

in experimental nonalcoholic fatty liver disease. J. Ayurveda Integr. Med., 1, 203-210.

Shukla, B., Visen, P.K., Patnaik, G.K. and Dhawan, B.N. (1991): Choleretic effect of picroliv, the hepatoprotective principle of Picrorhiza kurroa. Planta Med., 57, 29-33.

Simons, J.M., Hart, B.A., Ip Vai Ching, T.R., Van Dijk, H. and Labadie, R.P. (1990): Metabolic activation of natural phenols into selective oxidative burst agonists by activated human neutrophils. Free Radic. Biol. Med., 8, 251-258.

Singh, H. and Sharma, Y.K. (2011): Clinical evaluation of the hepatoprotective effect of Katuki (Picrorhiza kurroa Royle ex Benth.) processed in Guduchi (Tinospora cordifolia Wild.) Miers in patients receiving lipid lowering drugs (Statins). Ind. J. Trad. Knowledge, 10, 657-660 .
Singh, M., Tiwari, V., Jain, A. and Ghoshal, S. (2005): Protective activity of picroliv on hepatic amoebiasis associated with carbon tetrachloride toxicity. Indian J. Med. Res., 121, 676-682.

Singh, V., Visen, P.K., Patnaik, G.K., Kapoor, N.K. and Dhawan, B.N. (1992): Effect of picroliv on low density lipoprotein receptor binding of rat hepatocytes in hepatic damage induced by paracetamol. Indian J. Biochem. Biophys., 29, 428-432.

Snedecor, G.W. and Cochran, W.G. (1989): Statistical Methods 8th Edition, Iowa State University Press.

Visen, P.K., Saraswat, B. and Dhawan, B.N. (1998): Curative effect of picroliv on primary cultured rat hepatocytes against different hepatotoxins: an in vitro study. J. Pharmacol. Toxicol. Methods, 40, 173-179. 